\title{
Effectiveness of Monetary Policy is an Important Factor in the Sustainability of a Modern Economy
}

\author{
Natalia Iosifovna Kiriyakova ${ }^{1, *}$, Gaukhar Keniskhanovna Kalieva² \\ ${ }^{1}$ Ural State Economic University, Yekaterinburg, Russia \\ ${ }^{2}$ Karaganda University of Kazpotrebsoyuz, Karaganda, Kazakhstan \\ ${ }^{*}$ Corresponding author. Email: natashkir@yandex.ru
}

\begin{abstract}
This article considers the issue of the effectiveness of the monetary policy of the Bank of Russia in the context of the economy digitalization. The issue of the degree of participation of the Central Bank in regulating the economy becomes controversial with emergence of cryptocurrencies, which, according to some researchers, will cancel the Central Bank's monopoly on issuing funds. As a result, it becomes impossible to implement effective monetary policy. The author believes that emergence of cryptocurrencies creates the prerequisites for imbalances in the economy, therefore, presence of Central Banks in the regulation of monetary circulation is still necessary. However, this creates the need for a more flexible, adaptive control system. In recent years, the Bank of Russia has been using the key rate as such an instrument. Strengthening its differentiation, highlighting a neutral level and the possibility of fluctuations around it, make it possible to form an adaptive mechanism for regulating the monetary system, the level of inflation and the entire national economy.
\end{abstract}

Keywords: development sustainability; types of monetary policy; digitalization of the economy; adaptability of monetary policy; key rate; neutral key rate; nominal and real key rate; annual inflation; inflation targeting.

\section{INTRODUCTION}

The Sustainable Development Goals formulated by the $\mathrm{UN}$ as the most important perspective for the world economy until 2030, are becoming an important vector of development in the context of active digitalization. Noting the results of digital transformation, the economists emphasize the versatility of new digital technologies that are capable of constantly transforming themselves, gradually branching out and increasing productivity in all sectors and industries of the economy.

Under these conditions, a modern adaptation mechanism shall be developed, which is expressed not only in adoption of modern technologies, but also in adaptation to these technologies.

To effectively adapt to these conditions, it is necessary to combine the efforts of various countries, and within national economies, to combine the state, business and civil society. Also, an important role is played by the interconnection of various instruments of the state's economic policy, including monetary policy.
The types of monetary policy and the instruments that are used at the same time play an important role in adapting the economy to the new realities of development.

Traditionally, two types of monetary policy have been used: expansionary (policy of "cheap" money) and restrictive (policy of "expensive" money).

Both of these options have a fairly strong impact on the economy. However, as the experience of modern development shows, a neutral, on the one hand, and adaptive, on the other hand, version of monetary policy, which is becoming an important factor in the development sustainability, including in the modern Russian economy, is becoming increasingly important.

The adaptation mechanism means not only following the changing conditions, but also development of mechanisms related to the previous development, which allows to form stable expectations of the population and make the economy more stable, equilibrium, and balanced. 
Monetary policy neutrality implies setting a key rate that is in line with the inflation target. Also, the minimum deviation of the actual volume of production from the potential for a given economy is formed.

At a neutral level of the key rate, the economy grows at a rate close to the potential. A neutral level of the key rate implies the successful adaptation of the economy to the changed conditions, corresponds to its equilibrium, and stable state. Depending on the position of the key rate, a stimulating, restrictive or neutral monetary policy is distinguished.

In general, the effectiveness of monetary policy is becoming an important goal in the modern Russian economy development. Various types of interest rates used by Central banks, including the key rate of the Bank of Russia, which is actively used to form a certain monetary policy regime, are becoming important instruments in these conditions. [1]

Researches of scientists in this direction are numerous. The multidirectional impact of monetary policy on the economy is emphasized; various aspects of the impact of monetary policy regimes $[2,3]$ and the possibility of the impact of neutral monetary policy of the state [4] are considered. Influence of monetary policy on inflationary processes is investigated, since often the goals of economic regulation are reduced to targeting inflation [5].

Also, researchers pay a lot of attention to the analysis of the impact of digitalization on the economy [6], investigate the new role of the monetary system of the state in these conditions, identify the threats of the emergence of cryptocurrencies for financial stability. [7, 8] The importance of the most effective monetary policy measures, adaptability to digital technologies, which are capable of constantly transforming themselves, gradually branching out and increasing productivity in all sectors and branches of the economy, is growing in importance. Policies that maximize the benefits of the new technology and minimize short-term disruptions are necessary. The rate of adaptation and government policy responses will largely depend on the options chosen for the government's monetary policy.

Main topics of discussion:

1. Will the monopoly of the Central Bank on implementation of the emission of funds remain after the emergence of cryptocurrencies - argues Dong Hae, Deputy Director of the Department of Monetary Policy and Capital Markets of the International Monetary Fund. [9]

2. Will the Central Banks remain necessary as a result of progress in the field of information technology, asks Mervin King, the governor of one of the banks of the US Federal Reserve System and Charlie Goodhard, professor at the London School of Economics. [10, 11]
3. Will monetary policy remain effective without money issued by the Central Bank if cryptocurrency becomes widespread - Michael Woodford, an American economist, discusses the problem. [12]

4. Other researchers believe that well-thought-out policies can alleviate the short-term difficulties associated with the destabilizing effects of technology. Monetary policy development can benefit from new technologies if central banks expand their assessment of the current situation, improve forecasts through use of large databases. [13]

\section{MATERISLS AND METHODS}

The article presents the results of a study on impact of digitalization on changing the policy of the Central Bank, the possibilities of adapting the Bank of Russia to changing conditions by expanding the range of types of monetary policy, changing the key rate, money circulation rate, changing the reserve requirement. In these conditions, the Bank of Russia is expanding the range of financial services, increasing their availability, implementing measures to promote competition, and increasing information transparency. Communication policy is acquiring the role of an independent instrument of monetary policy.

The article examines the period of the Russian economy development from 2013 until 2021. Statistical data on the dynamics of the key rate in Russia, changes in the ratio between the nominal and real key rates considering the dynamics of inflation are provided.

The estimates were made using data from the website of the Bank of Russia, Rosstat.

\section{RESULTS AND DISCUSSION}

Modern Central Banks use not only the usual types of monetary policy: expansionary (policy of "cheap" money) and restrictive (policy of "expensive" money). Various "regimes" of monetary policy, using the "targeting" method, are also important. This can be inflation targeting, exchange rate targeting, money targeting, nominal GDP targeting, credit targeting, and interest rates targeting. In Russia, the inflation targeting method is most often used, although many researchers today believe that it is possible to abandon this and allow inflation to rise to $8 \%$ [14].

Nevertheless, in the context of inflation targeting, development becomes more predictable, favorable expectations of the population and the financial and non-financial sectors of the economy are formed.

When targeting inflation, the key rate becomes the main instrument of monetary policy. Its main task is to keep inflation at a given level (4\% in 2020). 
If the Bank of Russia fixes an inflationary rise in prices, then it raises the key rate. As a result, the cost of borrowed funds is growing, interest on bank deposits is growing, and the number of new debt securities is increasing.

The level of business activity is declining, but at the same time the rise in prices stops. In the opposite case, the actions of the Bank of Russia go in the opposite direction: the key rate goes down, the cost of credit resources goes down, business activity increases, but prices go up.

Also, the key rate determines the value of other types of interest rates, becomes a criterion for assessing the profitability of bonds and bank deposits, increases the inflow of foreign exchange, and affects the cost of various types of securities. If the key rate rises, then the demand for shares decreases and the demand for debt securities increases; with a decrease in the key rate, the opposite process occurs.

An increase in the key rate increases the attractiveness of Russian assets for foreign investors, since developed countries today are characterized by zero or even negative rates.

However, under the influence of rising inflation, the monetary policy of the Bank of Russia is tightening. The key rate is a variable indicator that depends on many factors, including the GDP dynamics.

According to government estimates, the GDP growth is expected by an average of $3 \%$ in the coming years. Such growth rates are sufficient to achieve the national development goals of the Russian economy until 2030. The growth in oil production under the OPEC + deal will have a strong impact on the GDP in the coming years.

Both monetary policy and the change in the key rate, in these conditions, shall have a restraining effect on the economy and prevent inflation from growing.

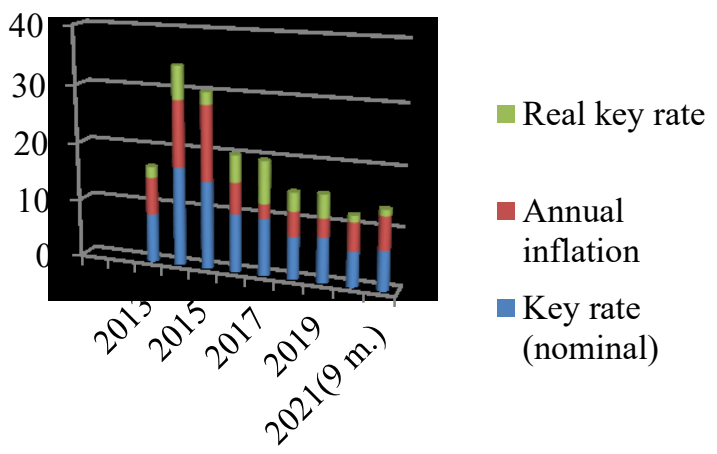

Source: compiled according to data from: www.cbr.ru

Figure 1 Dynamics of key rates and inflation in the Russian Federation

As the diagram shows (Fig. 1), since 2015, there is a continuous decline in the key rate, as the government seeks to accelerate the pace of growth of the Russian economy, despite the sanctions and the pandemic. In 2020, the nominal neutral key rate was $6 \%$, the inflation rate was $4 \%$, and the real key rate was $2 \%$. In the second half of 2021, according to government estimates, our country's economy has reached prepandemic levels.

This makes it possible to implement a balanced growth strategy. However, in modern conditions, after a pandemic, it is necessary to revitalize the economy. Therefore, the Bank of Russia in 2021 decides to raise the key rate up to $6.75 \%$, despite the fact that this creates conditions for inflationary price increases, since there are problems of outstripping population demand in comparison with an increase in production in the real sector of the economy. This increases inflationary expectations of the population. Based on Rosstat data, it can be seen that annual inflation by September 2021 increased to up to $6.68 \%$.

The adaptive mechanism is manifested by the monetary policy of the Bank of Russia in the alternation of changes in the key rate. This reflects the dynamics by months over the past 9 years.

Table 1. Change in the key rate of the Bank of Russia by months

\begin{tabular}{|c|c|c|c|c|c|c|c|c|c|c|c|c|}
\hline & \multicolumn{12}{|c|}{ Month } \\
\hline Year & 1 & 2 & 3 & 4 & 5 & 6 & 7 & 8 & 9 & 10 & 11 & 12 \\
\hline 2013 & & & & & & & & & 5,5 & 5,5 & 5,5 & 5,5 \\
\hline 2014 & 5,5 & 5,5 & 5,5 & 7 & 7,5 & 7.5 & 7,5 & 8 & 8 & 8 & 9,5 & 17 \\
\hline 2015 & 17 & 17 & 15 & 14 & 14 & 12,5 & 11,5 & 11,5 & 11 & 11 & 11 & 11 \\
\hline 2016 & 11 & 11 & 11 & 11 & 11 & 11 & 10,5 & 10,5 & 10,5 & 10 & 10 & 10 \\
\hline 2017 & 10 & 10 & 10 & 9,75 & 9,75 & 9 & 9 & 9 & 9 & 8,5 & 8,25 & 8,25 \\
\hline 2018 & 7,75 & 7,75 & 7,5 & 7,25 & 7,25 & 7,25 & 7,25 & 7,25 & 7,25 & 7,5 & 7,5 & 7,5 \\
\hline 2019 & 7,75 & 7,75 & 7,75 & 7,75 & 7,75 & 7,75 & 7,5 & 7,25 & 7,25 & 7,0 & 6,5 & 6,5 \\
\hline 2020 & 6,25 & 6,25 & 6,0 & 6,0 & 5,5 & 5,5 & 4,5 & 4,25 & 4,25 & 4,25 & 4,25 & 4,25 \\
\hline 2021 & 4,25 & 4,25 & 4,25 & 4,5 & 5 & 5 & 5,5 & 6,5 & 6,5 & 6,75 & - & - \\
\hline
\end{tabular}

Source: compiled according to data from: www.cbr.ru 
As can be seen from the table, the key rate, having replaced the refinancing rate in September 2013, initially simply supported the stability of the Russian economy and did not change for several months. After the imposition of sanctions, the Bank of Russia is increasingly beginning to use it as a mechanism for regulating the economy.

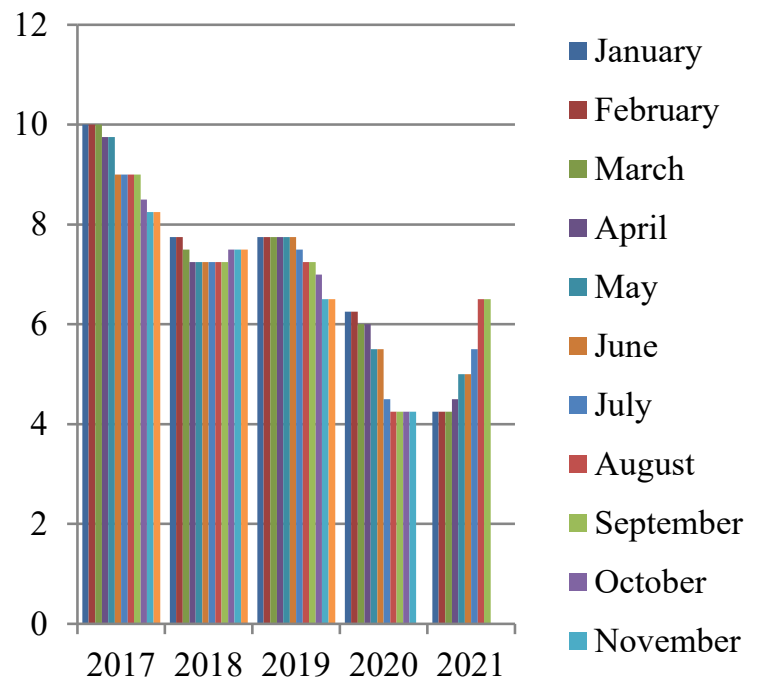

Figure 2 Change in the nominal key rate of the Russian Federation (by month)

The diagram shows the change in the nominal key rate of the Russian Federation by months, starting from 2017, when the change in the key rate turned into an important adaptive mechanism of influence on the economy of the Russian Federation.

The table shows the average positive relationship between the key rate and inflation (0.683839). The growth of the key rate does not stop the rise in prices, since Russian inflation is largely non-monetary in nature. Also, there is a weak positive relationship with the velocity of money circulation (0.37881), weak negative relationship with the GDP $(-0.27478)$, money supply $(-0.36717)$, the amount of required reserves (0.22684 ), since their dynamics determined by many of its own factors.

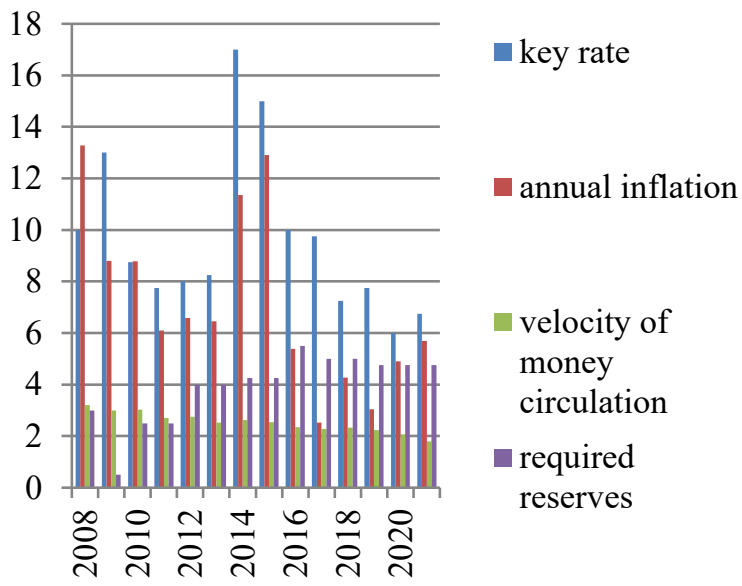

Figure 3 The relationship of the key rate, annual inflation, the speed of money circulation and mandatory reserves in the Russian Federation (by year)

Table 2. Correlation of interrelated indicators with changes in the key rate of the Bank of Russia

\begin{tabular}{|c|c|c|c|l|l|l|l|c|}
\hline $\begin{array}{c}\text { Perio } \\
\mathrm{d} \\
\left(\begin{array}{c}\text { year } \\
\text { ) }\end{array}\right.\end{array}$ & $\begin{array}{c}\text { Key rate } \\
\text { of the } \\
\text { Bank of } \\
\text { Russia }\end{array}$ & $\begin{array}{c}\text { Annual } \\
\text { inflation }\end{array}$ & Deposits & $\begin{array}{l}\text { Money } \\
\text { supply } \\
\left(\mathrm{M}_{2}\right)\end{array}$ & $\begin{array}{c}\text { Money } \\
\text { base }\end{array}$ & $\begin{array}{c}\text { Obligator } \\
\text { y } \\
\text { reserves }\end{array}$ & $\begin{array}{l}\text { Velocity } \\
\text { of } \\
\text { money } \\
\text { supply } \\
\text { circulati } \\
\text { on }\end{array}$ & $\begin{array}{c}\text { Nominal } \\
\text { GDP, } \\
\text { trillion } \\
\text { rub. }\end{array}$ \\
\hline 1 & 2 & 3 & 4 & 5 & 6 & 10 & 11 & 12 \\
\hline 2008 & 10 & 13,28 & 9046 & 12869 & 5202 & 3 & 3,2 & 41465 \\
\hline 2009 & 13 & 8,80 & 10113 & 12975 & 5218 & 0,5 & 2,99 & 38797 \\
\hline 2010 & 8,75 & 8,78 & 13644 & 15267 & 6945 & 2,5 & 3,03 & 44491 \\
\hline 2011 & 7,75 & 6,10 & 16445 & 20011 & 7465 & 2,5 & 2,7 & 54370 \\
\hline 2012 & 8 & 6,58 & 18757 & 24543 & 8257 & 4 & 2,75 & 58496 \\
\hline 2013 & 8,25 & 6,45 & 22309 & 27405 & 9138 & 4 & 2,53 & 66755 \\
\hline 2014 & 17 & 11,36 & 23222 & 31404 & 9951 & 4,25 & 2,62 & 79200 \\
\hline 2015 & 15 & 12,91 & 25968 & 32110 & 9887 & 4,25 & 2,54 & 83094 \\
\hline 2016 & 10 & 5,38 & 29116 & 35180 & 11184 & 5,5 & 2,35 & 86014 \\
\hline 2017 & 9,75 & 2,52 & 31410 & 40114 & 11596 & 5 & 2,29 & 92101 \\
\hline 2018 & 7,25 & 4,27 & 33996 & 44892 & 15695 & 5 & 2,33 & 103876 \\
\hline 2019 & 7,75 & 3,04 & 37770 & 47109 & 16500 & 4,75 & 2,24 & 105800 \\
\hline 2020 & 6 & 4,9 & 42002 & 51660 & 18632 & 4,75 & 2,05 & 106607 \\
\hline 2021 & 6,75 & 5,7 & 46797 & 59194 & 19371 & 4,75 & 1,8 & 111511 \\
\hline$r_{x y}$ & $\mathbf{( x )}$ & $\mathbf{0 , 6 8 3 8 3 9}$ & $\mathbf{- 0 , 3 6 1 6 3 4}$ & $\mathbf{- 0 , 3 6 7 1 7}$ & $\mathbf{0 , 4 6 2 4 0 5}$ & $\mathbf{- 0 , 2 2 6 8 4}$ & $\mathbf{0 , 3 7 8 8 1}$ & $\mathbf{- 0 , 2 7 4 7 8}$ \\
\hline
\end{tabular}

Source: compiled and calculated by the author based on the data from: www.cbr.ru 


\section{CONCLUSION}

In the context of digitalization of economic development, the role of Central Banks is becoming more complicated. However, they remain essential to the economy despite the emergence of cryptocurrency.

Study shows that using digital currencies has both benefits and risks. As correctly noted, "digital money expands the range of monetary policy options, stimulates competition and innovation in alternative financing payment systems for creation and distribution of money, and enhances the degree of monetization of the economy." [16]

In the constantly changing conditions of the functioning of the economy, the Central Banks and the Bank of Russia shall implement not only one direction of monetary policy, but, using an adaptive approach, choose an effective combination of instruments.

The key rate continues to play an important role in improving the effectiveness of monetary policy in these conditions in Russia.

\section{REFERENCES}

[1] N.I. Kiriyakova, Differentiation of interest rates in the money market is an important element of achieving a balance between the money and real sectors of the economy, Economics and Entrepreneurship, 8(4)(85-4) (2017) pp. 877-881.

[2] T.I. Gordievich, P.V. Ruzanov, Monetary policy: basic modes and transmission mechanism, Omsk Scientific Bulletin. Ser. Society. History. Modernity, 4(2) (2020) pp. 122-130.

[3] E.V. Rogatenyuk, Comparative characteristics of the regimes for implementation of monetary policy (targeting regimes), Economy of construction and environmental management, 3(64) (2017) pp. 6774.

[4] V.K. Krylov, Macroeconomic equilibrium and neutral monetary policy, University Bulletin., 8 (2020) pp. 149-154.

[5] A.V. Bozhechkova, P.V. Trunin, Monetary policy and inflation: results of 2020, Economic development of Russia., 28(1) (2021) pp. 4-6.

[6] N.I. Kiriyakova, Digital Currencies of the CentralBank as a Means of Strongthening the Monetization of the Russian Economy, http://creativecommons.org/licenses/by-c/40/.1155.

[7] D. Dragopoulos, F. Natalucci, E. Papageorgiu, The boom in the crypto asset market is a threat to financial stability, Global Financial Stability Report, International Monetary Fund, https://www.imf.org/ru/Publications/GFSR/Issu es/2021/10/12/global-financial-stability-reportoctober-2021.

[8] B. Friedman, Decoupling at the Margin: The Threat to Monetary Policy from the Electronic Revolution inBanking, International Finance, 3(2) (2000) pp. 261-72.

[9] He. Dong, Due to crypto assets, the demand for central bank money may decrease one day, Monetary policy in the digital age, Finance and Development. IMF Quarterly Magazine, 2018.

[10] T. Adrian, T. Mancini-Griffoli, The Rise of Digital Money, IMF FinTech Note, 19/01 (2019).

[11] M. King, Challenges for Monetary Policy: New and Old. Speech delivered atasymposiumsponsored by the Federal Reserve Bank of Kansas City, Jackson Hole, WY, 1999.

[12] Ch. Goodhart, Can Central Banking Survive the ITRevolution?", In: International Finance, 3(2) (2000) pp. 189-209.

[13] M. Woodford, Monetary Policy in a World without Money, In: International Finance, 3(2) (2000) pp. 229-60.

[14] C. Lagarde, We must protect ourselves from financial risks without hindering innovation, Regulation of financial technologies, Finance and Development. IMF Quarterly Magazine, 2018.

[15] S.Yu. Glazyev, Potential Growth Opportunities for the Russian Economy and the Monetary Policy of the Bank of Russia, Economic and Social Changes: Facts, Trends, Forecast., 11(5) (2018) pp. 30-49.

[16] N.I. Kiriyakova, Digital Currencies of the CentralBank as a Means of Strongthening the Monetization of the Russian Economy, Copyright, The Authers Press SARL, 2000. http://creativecommons.org/licenses/by-c/40/.1155. 